\title{
Prevalence of chronic pain among elderly living in a city of Northern Rio Grande do Sul
}

\author{
Prevalência de dor crônica em homens idosos de um município do norte do Rio Grande do Sul
}

Daniel Rodrigues ${ }^{1}$, Ezequiel Vitório Lini' ${ }^{1}$, Andréia Mascarelo ${ }^{1}$, Marilene Rodrigues Portella1 ${ }^{1}$, Marlene Doring ${ }^{1}$

DOI 10.5935/1806-0013.20160071

\section{ABSTRACT}

BACKGROUND AND OBJECTIVES: Chronic pain is a problem for the elderly, eliciting physical and psychological limitations. Few are the studies primarily focusing on evaluating pain in men. This study aimed at identifying the prevalence of chronic pain in male elderly people of a city of Northern Rio Grande do Sul.

METHODS: Crossover, population-based study carried out with people aged 60 years or above, from the city of Coxilha, state of Rio Grande do Sul. Data were collected by home interviews with validated tool from June to July 2010. Descriptive statistics was used for analysis.

RESULTS: Mean age was 68.7 years. Chronic pain prevalence was $43.7 \%$, primarily located in lower limbs and lumbar spine.

CONCLUSION: There has been high prevalence of chronic pain in the studied population. Results point to the need for intervention strategies to prevent and control pain in elderly males in different health care levels.

Keywords: Chronic pain, Daily activities, Elderly, Epidemiology, Pain perception.

\section{RESUMO}

JUSTIFICATIVA E OBJETIVOS: A dor crônica é um problema presente na vida dos idosos, provocando limitaçóes físicas e psicológicas. São poucas as análises que têm como foco principal a avaliação da dor no homem. O objetivo deste estudo foi identificar a prevalência de dor crônica em idosos do gênero masculino em um município do norte do Rio Grande do Sul.

MÉTODOS: Estudo transversal de base populacional, realizado com pessoas de 60 anos ou mais, do município de Coxilha, es-

\footnotetext{
1. Universidade de Passo Fundo, Passo Fundo, RS, Brasil.
}

Submitted in April 22, 2016.

Accepted for publication in July 26, 2016.

Conflict of interests: none - Sponsoring sources: none.

Correspondence to

Rua Teixeira Soares, 817 - Centro

99010-080 Passo Fundo, RS, Brasil.

E-mail: danicamini88@gmail.com

() Sociedade Brasileira para o Estudo da Dor tado do Rio Grande do Sul. A coleta dos dados foi realizada por inquérito domiciliar com instrumento validado entre junho e julho de 2010. Na análise, empregou-se a estatística descritiva.

RESULTADOS: A média de idade foi de 68,7 anos. A prevalência de dor crônica foi de $43,7 \%$, localizada principalmente nos membros inferiores e na região lombar.

CONCLUSÃO: Identificou-se alta prevalência de dor crônica na população estudada. Os resultados apontam para a necessidade de se estabelecerem estratégias de intervenção para a prevenção e o controle da dor em homens idosos nos diferentes níveis de atenção à saúde.

Descritores: Atividades diárias, Dor crônica, Epidemiologia, Idoso, Percepção da dor.

\section{INTRODUCTION}

With world population aging, chronic diseases and pain complaints have become more frequent. Increased life expectation is pronounced, especially in developing countries. This unquestionable reality brings implications to society and to the health system, such as increased comorbidities associated to pain complaints ${ }^{1}$.

Demographic transition and longevity imply the incidence of chronic and disabling diseases which may lead to increased dependence, pain complaints, further trend to complications and chronicity ${ }^{2}$. Chronic pain $(\mathrm{CP})$ is a frequent complaint among the elderly and may impair functionality ${ }^{3}$.

Types of chronic pain may differ in location and intensity. With regard to manifestation, it may be persistent or recurrent for a period of three months or longer ${ }^{2-4}$. Such conditions are major disabling factors for the quality of life of the elderly, because they limit their activity, increase agitation, risk for stress and social isolation ${ }^{5}$. They might be related to chronic pathologic processes which last for months or years and, in some cases, pain is major complaint and reason for functional limitation. CP may last beyond the healing period, persisting for months or years, associated or not to other chronic diseases ${ }^{3,6}$.

Pain is a presumable experience to all individuals and may be experienced in some moment of life ${ }^{7}$. It is considered a public health problem, affects a significant number of the elderly segment, brings personal and economic repercussions and impairs quality of life $e^{6,8}$. So, it is important to invest in studies on CP epidemiology in different contexts. Chronicity may interfere with different aspects of life and 
sometimes it impairs mental health as a consequence of psychic distress. For some individuals, interference reaches labor activities, for others, it affects daily life activities and there are still cases of social and leisure activities isolation?. Prevalence of CP among males is poorly studied in the literature, since many studies are dedicated to this condition in females with indication that the number of males referring pain is lower than that of females ${ }^{10}$, which justifies an investigation in this population segment.

The relevance of the study is centered in the fact that elderly population growth elicits different types of demands. With regard to chronic conditions, costs affect the elderly, their families and the health system.

In light of the above, this study aimed at identifying the prevalence of chronic pain in male elderly people in a city of the Northern Rio Grande do Sul.

\section{METHODS}

This is a crossover population-based study, part of a broader research called "Life and health conditions of the elderly of the city of Coxilha-RS", carried out in 2011. Coxilha is considered a small city to the North of Rio Grande do Sul. Population, according to the latest census of the Brazilian Institute of Geography and Statistics (IBGE), was 2826 inhabitants. The Basic Attention Information System (SIAB) was queried for elderly segment screening, based on February 2010 , which has identified 352 individuals aged 60 years or above ${ }^{11}$.

Study population was made up of all elderly males living in the city, having as inclusion criteria to be living for at least six months in the city and have the ability to understand and verbalize to answer the questionnaire and/or have the presence of a family member or caregiver to help or to answer the questions.

There has been $8.5 \%$ loss due to refusal to participate or for not having been found after three visit attempts in alternate days and times. With this, the group was made up of 331 participants. From them 158 were males and make up the population of this study. Data were collected by means of home interviews, using an adaptation of the structured questionnaire of the study "Health, wellbeing and aging" $(\mathrm{SABE})^{12}$ between June and July 2010 . Such tool is validated in Brazil for people aged 60 years or above, is easy to apply and is very reliable. The tool has seven sections: a) personal and family information, b) cognitive evaluation, c) housing conditions, d) health and lifestyle conditions, e) functional evaluation, f) use and access to health services and g) family and social support.

Dependent variable was self-referred chronic pain. Independent variables were part of section A (gender, marital status, education level, income, housing and working place); of section $\mathrm{D}$ (pain location, history of falls in the last year, practice of physical activity, health self-evaluation, use of drugs) and of section E basic daily life activities (BDLA).

Data were analyzed by descriptive statistics. Chi-square test was used to observe the association between categorical variables with significance level of $5 \%$.

The project was approved by the Research Ethics Committee, Universidade de Passo Fundo, protocol 148/2010 with approval of the legal representative of the city of CoxilhaRS. All participants have signed the Free and Informed Consent Term (FICT).

\section{RESULTS}

Participated in the study 158 males aged $\geq 60$ years. Mean age was $68.7 \pm 7.1$ years. Among respondents, there has been predominance of whites $(69.6 \%)$ and $53.8 \%$ of the elderly lived in the urban area. Predominant marital status was married $(87.3 \%)$. With regard to education level, $40.5 \%$ of respondents had 4 to 7 years of study. Prevalence of CP was $43.7 \%$ (Table 1).

As to location, most elderly have referred low back pain, followed by lower limbs and shoulders (Table 2).

There has been significant association between CP, practice of physical activity, health self-evaluation and BDLA. From the elderly referring $\mathrm{CP}, 62.3 \%$ did not practice physical activity $(\mathrm{p}=0.006), 68.1 \%$ have self-evaluated their health as regular, poor or very poor $(\mathrm{p}<0.001)$, and $42 \%$ have referred difficulties to perform BDLA ( $\mathrm{p}=0.001)$ (Table 3). There has been no association between $\mathrm{CP}$, housing area, current job, education level, use of drugs, falls in the last year and income ( $\mathrm{p}>0.05)$.

Table 1. Socio-demographic variables

\begin{tabular}{|c|c|c|c|}
\hline & \multicolumn{2}{|c|}{ Chronic pain } & \multirow[t]{3}{*}{$p$ value } \\
\hline & Yes & No & \\
\hline & $\mathrm{n}(\%)$ & n (\%) & \\
\hline \multicolumn{4}{|l|}{ Marital status } \\
\hline Separate & $2(28.5)$ & $5(71.5)$ & 0.355 \\
\hline Widower & $4(40)$ & $6(60)$ & \\
\hline Married & $63(45.6)$ & 75 (55.34) & \\
\hline Single & $0(0)$ & $3(100)$ & \\
\hline \multicolumn{4}{|l|}{ Education (years) } \\
\hline Illiterate & $11(30.5)$ & $25(69.5)$ & 0.513 \\
\hline 1 to 3 & $29(47)$ & $32(53)$ & \\
\hline 4 or + & $18(36)$ & $32(74)$ & \\
\hline \multicolumn{4}{|l|}{ Income (MW) } \\
\hline Up to 1 & $21(45.6)$ & $25(54.4)$ & 0.441 \\
\hline Between 1 and 2 & $29(47.5)$ & $32(52.5)$ & \\
\hline 4 or more & $18(36)$ & $32(74)$ & \\
\hline \multicolumn{4}{|l|}{ Dwelling zone } \\
\hline Urban & $36(42.3)$ & $49(57.7)$ & 0.719 \\
\hline Rural & $33(45.2)$ & $40(54.8)$ & \\
\hline \multicolumn{4}{|l|}{ Currently working } \\
\hline Yes & $37(42)$ & $51(58)$ & 0.644 \\
\hline No & $32(45.7)$ & 38 (54.3) & \\
\hline
\end{tabular}

$\mathrm{MW}=$ minimum wage. 
Table 2. Pain site

\begin{tabular}{lc}
\hline & $\mathrm{n}(\%)$ \\
\hline Low back & $112(67.4)$ \\
Lower limbs & $67(40.4)$ \\
Shoulders, arms and hands & $44(26.5)$ \\
Head, face or mouth & $26(15.7)$ \\
Abdomen & $25(15.1)$ \\
Chest & $17(10.2)$ \\
Neck & $13(7.8)$ \\
Pelvis & $10(6 \%)$ \\
Feet & $8(4.8)$ \\
Anal and genital region & $2(1.2)$ \\
\hline
\end{tabular}

Table 3. Clinical variables

\begin{tabular}{|c|c|c|c|}
\hline & \multicolumn{2}{|c|}{ Chronic pain } & \multirow[t]{3}{*}{$p$ value* } \\
\hline & Yes & No & \\
\hline & n (\%) & n (\%) & \\
\hline \multicolumn{4}{|l|}{ Fall in the last year } \\
\hline Yes & $12(40)$ & $18(60)$ & 0.652 \\
\hline No & $57(44.5)$ & $71(55.5)$ & \\
\hline \multicolumn{4}{|l|}{ Physical activity } \\
\hline Yes & $26(32.9)$ & $53(67.1)$ & 0.006 \\
\hline No & $43(54.4)$ & $36(45.6)$ & \\
\hline BDLA & & & 0.001 \\
\hline No difficulty & $40(35.4)$ & $73(64.6)$ & \\
\hline With difficulty & $29(64.4)$ & $16(35.6)$ & \\
\hline \multicolumn{4}{|l|}{ Health self-evaluation } \\
\hline Very good/good & $22(27.8)$ & $57(72.2)$ & $<0.001$ \\
\hline Regular/poor/very poor & $37.3(36)$ & $79(62.7)$ & \\
\hline \multicolumn{4}{|l|}{ Use drugs } \\
\hline Yes & $50(45.5)$ & $60(54.5)$ & 0.494 \\
\hline No & $19(39.6)$ & $29(60.4)$ & \\
\hline
\end{tabular}

\section{DISCUSSION}

Pain perception is a set of combinations and interpretations of individual factors such as mood, health self-evaluation, previous experiences, beliefs, attitudes, knowledge and symbolic signs attributed to pain ${ }^{13,14}$.

The prevalence of CP in this study was similar to findings of the crossover study carried out in Londrina/ $/ \mathrm{PR}^{15}$ where, from 71 male elderly, 52\% have reported CP with similar pain location for lower limbs (31.4\%), however lower for low back pain (30.2\%).

Celich \& Galon ${ }^{16}$, in a crossover study with elderly living in the city of Cruzaltense/RS, have found similar results, with prevalence of $40.7 \%$ of $\mathrm{CP}$ among males. As to pain sites, and similar to our study, lumbar region was the most affected region $(44 \%)^{16}$.

There has been relationship between CP and not practicing physical activity. This finding confirms a study by Souza ${ }^{17}$ on the effect of physical activity on CP. The author concludes that it is possible to decrease pain intensity because moderate aerobic physical exercise maintained for more than 10 minutes may activate endogenous pain control mechanisms, may improve strength and muscle resistance, wellbeing and quality of life, improving ability to perform BDLA ${ }^{17}$.

Similarly, studies show that the elderly practicing physical activities had lower prevalence of CP in addition to better quality of life ${ }^{13,18}$. A study in the city of Florianópolis ${ }^{10}$ with 1656 elderly has observed that being physically active was associated to lower chronic pain prevalence ${ }^{10}$.

In our study, there has been association between $\mathrm{CP}$ and difficulty to perform BDLA among the elderly. CP is a disabling condition directly interfering with daily life activities $^{16}$. Dellaroza et al. ${ }^{3}$, in a study in the city of São Paulo, have shown that chronic pain was associated to worse functional capacity evaluated by means of basic and instrumental daily life activities ${ }^{3}$.

Our results have shown association between health selfevaluation as regular, poor and very poor and CP. Health self-perception is a major health indicator and involves a series of factors, such as physical, cognitive and emotional aspects $^{7}$. Studies ${ }^{7,19}$ have shown that CP might be associated to depression, physical and functional incapacity, dependence, social isolation and hopelessness ${ }^{19}$. Such factors may lead the elderly to a negative self-perception of health ${ }^{13,19}$.

The crossover design does not allow the establishment of a causal proof for CP, which results in a limitation of this study. On the other hand, investigating $\mathrm{CP}$ in males is the relevance of the study, because this segment is poorly explored in the Brazilian literature.

\section{CONCLUSION}

There has been high prevalence of elderly males with CP which was associated to not performing physical activity, difficulty to perform BDLA and negative self-evaluation of health. Most affected sites were lumbar region and limbs. These findings provide visibility to the $\mathrm{CP}$ problem among elderly males. Actions aiming at preventing and decreasing chronic pain in males are possible to be established provided that predisposing factors are identified by the health team.

\section{REFERENCES}

1. Gonçalves LG, Vieira ST, Siqueira FV, Hallal PC. [Prevalence of falls in institutionalized elderly in Rio Grande, Southern Brazil]. Rev Saude Publica. 2008;42(5):938-45. Portuguese.

2. Mongil RL, Trigo JAL. Prevalencia y fisiopatologia del dolor crónico en el anciano. In: Gregorio PG (coord). Guía de buena práctica en geriatria: dolor crónico em el anciano.Sociedad Española de Geriatría y Gerontología. Madrid: IMC; 2013. 9-24p.

3. Dellaroza MS, Pimenta CA, Duarte YA, Lebrão ML. [Chronic pain among elderly residents in Săo Paulo, Brazil: prevalence, characteristics, and association with functional capacity and mobility (Sabe Study)]. Cad Saude Publica. 2013;29(2):325-34. Portuguese.

4. Oliveira MA, Fernandes RS, Daher SS. Impacto do exercício na dor crônica. Rev Bras Med Esporte. 2014;20(3):200-3.

5. Dellaroza MS, Pimenta CA, Matsuo T. [Prevalence and characterization of chronic pain among the elderly living in the community]. Cad Saude Publica. 2007;23(5):1151- 
60. Portuguese.

6. van Hecke O, Torrance N, Smith BH. Chronic pain epidemiology and its clinical relevance. Br J Anaesth. 2013;111(1):13-8.

7. Alves JP. Caracterizaçăo dos níveis de atividade física das pessoas com 75 anos ou mais anos e a sua relaçăo com a autopercepção de saúde e a dor [dissertação]. Setúbal: Instituto Politécnico de Setúbal; 2012. 131p.

8. Silveira MM, Pasqualotti A, Colussi EL. Prevalência de dor crônica em adultos e idosos. Rev Bras Ciências Saúde. 2012;10(31):39-44.

9. Salvetti Mde G, Pimenta CA, Braga PE, Corrêa CF. [Disability related to chronic low back pain: prevalence and associated factors]. Rev Esc Enferm USP. 2012;46(Spe $\left.n^{\circ}\right): 16-23$. Portuguese.

10. dos Santos FA, de Souza JB, Antes DL, d'Orsi E. [Prevalence of chronic pain and its Association with the sociodemographic situation and physical activity in leisure of elderly in de Florianópolis, Santa Catarina: population-base study. Rev Bras Epidemiol. 2015;18(1)234-47. English, Portuguese.

11. Coxilha. História do município. [acesso em 26 de setembro de 2015]. Disponível em: http://www.pmcoxilha.rs.gov.bv/pagina/495/historia.

12. Lebrăo ML, Laurenti R. Saúde, bem-estar e envelhecimento: o estudo SABE no Mu- nicípio de Săo Paulo. Rev Bras Epidemiol. 2005;8(2):127-41.

13. Silva MF, Goulart NB, Lanferdini FJ, Marcon M, Dias CP. Relação entre os níveis de atividade física e qualidade de vida de idosos sedentários e fisicamente ativos. Rev Bras Geriatr Gerontol. 2012;15(4):634-42.

14. Budó Mde L, Nicolini D, Resta DG, Büttenbender E, Pippi MC, Ressel LB. [Culture permeating the feelings and the reactions in the face of pain]. Rev Esc Enferm USP. 2007; 41(1):36-43. Portuguese.

15. Dellaroza MS, Furuya RK, Cabrera MA, Matsuo T, Trelha C, Yamada KN, et al [Characterization of chronic pain and analgesic approaches among community-dwelling elderly]. Rev Assoc Med Bras. 2008;54(1):36-41. Portuguese.

16. Celich KL, Galon C. Dor crônica em idosos e sua influência nas atividades da vida diária e convivência social. Rev Bras Geriatr Gerontol. 2009;12(3):345-60.

17. Souza JB. Poderia a atividade física induzir analgesia em pacientes com dor crônica? Rev Bras Med Esporte. 2009;15(2):145-50.

18. Krug RR, Lopes MA, Mazo GP, Marchesan M. A dor dificulta a prática de atividade física regular na percepção de idosas longevas. Rev Dor. 2013;14(3):192-5.

19. Dellaroza MS, Pimenta CA. Impacto da dor crônica nas atividades de vida diária de idosos da comunidade. Ciênc Cuid Saúde. 2012;11(Suppl):235-42. 